\title{
Od pandemie k revitalizaci: čínská zkušenost s koronavirem a globální iniciativy
}

\author{
Milan Kreuzzieger - Marek Hrubec \\ Filosofický ústav Akademie věd ČR, CZ - Filosofický ústav \\ Akademie věd ČR, $\mathrm{CZ}$
}

KREUZZIEGER, M.-HRUBEC, M.: From the Pandemic to Revitalization. The Chinese Experience with Coronavirus and Global Initiatives

Philosophica Critica, vol. 6, 2020, no. 1, ISSN 1339-8970, pp. 103-117

The article deals with the Chinese experience with the contemporary pandemic in relation to relevant social and political issues. It addresses how China went from struggles against coronavirus (and related COVID-19) to a gradual revitalization of its economy and society after the (first) wave of the coronavirus. It analyses seven aspects of this issue. First, an identification of coronavirus and anti-virus measures applied by the government. Second, the spreading of the epidemic. Third, an ideological war in the world of multiple modernities. Fourth, a transition from the standstill of economy to its revitalization. Fifth, the historical Silk Road and its modernization. Sixth, the global Belt and Road Initiative and scenarios of future development. Seventh, the 17+1 Cooperation of China with Central and Eastern European countries.

Key words: China - Chinese - Pandemic - Coronavirus - COVID-19 Global - Belt and Road

„Souhlas a přitakání - čím se od sebe liší?

Dobré a zlé - jaký je mezi nimi rozdíl?

Avšak: čeho se lid hrozí,

Toho se nelze nehrozit."

Lao-c', O tao a ctnosti (překl. B. Krebsová, DharmaGaia, Praha 2003, s. 69).

Stejně jako každá nová závažná nemoc zasahující značnou část populace, je COVID-19 předmětem intenzivního vědeckého výzkumu, občanských a politických reakcí, mediálního zájmu a nesčetných dalších diskusí, které 
se snaží zjistit o nemoci a jejím šíření co nejvíce informací. Nemoc způsobená novým koronavirem (SARS-CoV-2) byla oficiálně poprvé identifikována v čínském městě Wu-chan s 11 miliony obyvatel v provincii Chu-pej v prosinci 2019 a pojmenována Světovou zdravotnickou organizací (WHO) jako COVID-19 v únoru 2020. Počátek a původ nemoci jsou ovšem stále předmětem vědeckého výzkumu. Rostoucí křivku osob zasažených virem se v Číně podařilo stabilizovat ve druhé polovině února 2020 s uváděnými údaji mírně nad osmdesáti tisíci infikovanými případy a počtem obětí přes tři tisíce osob. Lze uvést, že k dnešnímu dni (5. května 2020) je uváděno celosvětově více než 3,7 milionu nakažených a více než 258 tisíc obětí, z toho v Číně je hlášeno registrovaných 82881 nakažených a 4633 obětí (Worldometers 2020). Největší výpovědní hodnotu mají tato čísla hlavně vzhledem k možnosti sledovat vývojové trendy a porovnávat metody výpočtů, které se navíc $v$ průběhu času mění, at' už v národním rámci či v globální komparaci. Například zjištování, kolik lidí má nemoc bez příznaků, se stává předmětem výzkumu v řadě zemí světa a bude záležet na míře testování, úspěšné identifikaci a registraci postižených. V tomto eseji se zaměříme především na vládní opatření proti koronaviru a na jejich reakce ve společenské a politické sféře.

\section{Identifikace koronaviru a antivirová opatření}

Koronavirová pandemie je závažný problém, jenž vyžaduje respekt k lidským životům a snahu o omezování projevů paniky, běžných sporů a xenofobních a rasistických projevů. Vzhledem k záplavě často protichůdných mediálních informací je vhodné nejprve stručně popsat jednotlivé realizované klíčové organizační kroky podle hlavních dostupných zdrojů, což přinejmenším umožňuje mapovat sled přijatých opatření. Jelikož byla nemoc čínskými lékaři identifikována jako dosud neznámá choroba s příznaky podobnými chřipce či zápalu plic, vyžádala si nejprve určitý čas pro její přesnou detekci a potvrzení.

Ve veřejných zdrojích jsou dobře dostupné informace o tom, že v prosinci došlo k prvním upozorněním na podezřelé výskyty a na polemiku o tom, zda se jedná o novou nemoc a jak je nebezpečná. Nastala šetření různých případů a následně byly tři případy nemoci oficiálně zkoumány Oddělením respirační a kritické péče v Nemocnici provincie Chu-pej pro integrované tradiční čínské a západní lékařství. Epidemiologická vyšetření byla nemocnicím a střediskủm pro kontrolu a prevenci nemocí v městě Wu-chanu a v provincii Chu-pej nařízena od 29. prosince 2019. Městský zdravotnický výbor ve Wu-chanu vydal urgentní oznámení o léčbě pneumonie neznámé příčiny 30. prosince, přičemž tím byly zahájeny práce 
odborníků z dalších oblastí. Světová zdravotnická organizace a různé země začaly dostávat pravidelné informace od 3. ledna 2020 včetně evropských zemí a USA. Poté 7. ledna čínské zdravotnické instituce potvrdily, že nový koronavirus byl spojen s př́ípadem na trhu ve Wu-chanu. Čínské centrum pro kontrolu a prevenci nemocí oznámilo pět celých genomových sekvencí nového koronaviru Světové zdravotnické organizaci a dalším zájemcům na webových stránkách 11. ledna. Virus se dostal do dalších zemí, například první oficiálně potvrzený případ COVID-19 v USA byl zaznamenán 20. ledna. V Číně se postupně činila různá antivirová opatření a 23. ledna bylo zcela uzavřeno město Wu-chan s př́ísnými opatřeními. Přestože jsou udávány ještě další různé údaje, nemění podstatně základní časový vývoj událostí včetně skutečnosti, že oproti Číně, v níž epidemie propukla, měly evropské země, USA a další země výhodu, že se jim dostalo informací o problému předem. Nicméně vždy budou existovat vzájemné požadavky zemí, aby se informovaly lépe a více, což je možné oboustrannou spoluprací vylepšovat. Nejde však pouze o informace, ale hlavně o vzájemnou pomoc při zachraňování životů a zdraví lidí.

\section{Šíření pandemie}

Souhrnně lze říci, že zásadní opatření byla přijata v lednu 2020 poté, kdy se postupně ukázaly odlišné závažné př́íznaky a schopnost nemoci se v lidské populaci rychle šírit (virulence). Když nemoc začala postihovat stále více osob, byla zavedena restriktivní opatření zamezující přenos viru a město $\mathrm{Wu}$-chan a okolní tři města v provincii Chu-pej byla uzavřena. Zároveň s rychle narůstajícím počtem případů byla posílena zdravotnická infrastruktura intenzivní výstavbou několika specializovaných nemocnic a povoláním zdravotníků, hygieniků, dobrovolníků, policie a armády. Neštastný byl ale souběh s tím, že Wu-chan před uzavřením opustilo mnoho lidí. Jak potvrdila Světová zdravotnická organizace, Čína poskytla odborníkům z celého světa velké množství odborných informací a zkušeností včetně popisu genomu koronaviru, který je důležitý pro vývoj vakcíny. Mezitím se však nákaza rozšíŕila do mezinárodního prostoru (asijských zemí, Evropy, na Blízký východ, USA ad.), kde způsobila řadu reakcí: od počáteční přezíravosti k panice, od přijetí přístupu divokého „promořování" s cílem získat „kolektivní imunitu“ přes řízené zmírňování postupu (mitigation) až po aktivní potlačování (suppression) spojené se snahou nepřetížit zdravotnický systém i možnosti dané společnosti a omezit a oddálit šíření viru, než bude dostupný lék a vakcína.

Jelikož byla Čína první zemí, v níž se koronavirus rozšiŕili, volba čínských antivirových opatření sloužila jako model, který byl vystaven testu, 
zda uspěje, nebo ne. Ostatní země se mohly mezitím částečně připravit na šíření viru a rozhodnout se pro vhodná opatření. Čínská vláda přijala velmi restriktivní opatření včetně domácí karantény, povinného nošení roušek a respirátorů, zavření obchodů, zastavení části průmyslové výroby apod. Čína podobně jako řada dalších zemí ve východní a jihovýchodní Asii má zkušenost s nebezpečnými nemocemi z dávnější minulosti i z nedávné doby. Jestliže se epidemie ve středověku šírily z Číny směrem do Evropy a naopak často celá léta, pak v současné době, kdy je svět propojen v důsledku vysoké mobility osob, mezinárodního obchodu a obecně celosvětové provázanosti, nastává šíření nemocí v řádu dní až týdnů.

Je patrné, že východoasijské země byly na epidemii lépe připraveny než Evropa nebo USA i v důsledku předchozí zkušenosti především s nemocí SARS (Severe Acute Respiratory Syndrome, syndrom náhlého selhání dýchání), v letech 2002-2003 způsobenou také virem ze skupiny koronavirů (zasáhla téměř deset tisíc lidí se smrtností přibližně $10 \%$ ). Tyto země se s epidemií zatím relativně úspěšně vyrovnávají díky vládním opatřením, organizovanosti velkého množství lidí, disciplíně a pochopení mechanismů šíření nemoci, a to v některých případech i bez plošné karantény doprovázené výrazným pozastavením veškerého života i celé ekonomiky. Reakce lidí jsou patrné i v západních zemích. Porovnáváme-li reakce jedinců i celých čínských komunit žijících $\mathrm{v}$ „angloamerickém prostoru“, především v USA a Velké Británii, je u nich často zřejmá ochota přizpůsobit se kolektivnímu rozhodnutí institucionálních a politických autorit, zatímco u většiny ostatních lidí tomu tak v západních zemích ve velké míře není. V Evropě a Severní Americe byly SARS, ebola, virus zika a jiné nakažlivé nemoci brány jako riziko, ale vnímané spíše jako vzdálené nemoci. Čína a další východoasijské země, například Jižní Korea či Singapur, přitom patrně dokázaly využít nových digitálních technologií pro monitoring a šiřrení nemoci. To jim umožnilo cílenější boj s nemocí.

\section{Ideologická válka ve světě různorodých modernit}

Koronavirová pandemie se stala rovněž podnětem pro vznik několika hypotéz, případně až sporných dohadů, které zaujaly masová média. Prezident USA prosazuje verzi, že virus pochází z wu-chanských laboratoří. Americké zpravodajské služby přitom však uvádějí, že jsou tlačeny $\mathrm{k}$ tomu, aby toto tvrzení potvrdily (Wintour 2020; Mazzetti 2020). Podle jiné interpretace by mohlo jít o virus přivezený sportovci americké armády na sportovní armádní hry ve Wu-chanu v ř́ijnu 2019 (Pickrell et al. 2020). Další interpretací je propojení čínského a amerického vlivu tím, že americké vládní zdroje údajně financovaly experimenty ve wuchanské laboratoři 
(Mulraney - Owen 2020). Zatím je však většinově přijímán vědecky podložený názor, že koronavirus prošel přirozeným evolučním vývojem a nebyl vytvořen uměle v laboratorních podmínkách, jak uvádí také kancelář ředitele amerického zpravodajství, čínské vedení i Světová zdravotnická organizace (World Health Organization 2020). Nicméně předmětem tohoto článku není rozbor virologických či epidemiologických problémů a jejich počátky. Pokud by však politické zneužívání této otázky zesílilo, bylo by nutné se jí více věnovat.

Různá obvinění souvisejí zatím nejvíce s vývojem epidemie v USA. Nejprve prezident Trump chválil čínského prezidenta za zvládání epidemie, ale obrátil poté, když nebyl se svojí vládou schopen zvládnout pandemii a USA se staly zemí, která má největší počet nakažených a mrtvých v důsledku pandemie na světě (konkrétně nyní má celou třetinu nakažených, tj. více než 1,2 milionu osob). V této situaci začal americký prezident vznášet otázku po včasném informování. Nicméně Centrum pro kontrolu a prevenci nemocí a velvyslanectví USA vydaly již 7. ledna oznámení, aby lidé necestovali do Wu-chanu, tj. třináct dní před oficiálním oznámením prvního př́padu koronaviru v USA (viz výše). Na konci února hodnotil prezident Trump riziko nemoci pro USA stále jako nízké a ještě v březnu byl optimistický.

Stojí ovšem za to zmínit, že pokusy dodat této otázce politickou sílu nastaly, přestože mají dosud spíše jen charakter rétoriky nízké závažnosti. S expanzí nákazy se projevují i snahy využít epidemii pro rozpoutání ideologické války. Zaznívají označení jako „čínský virus“, kdy se projevují xenofobní a rasistické předsudky a vyvolávání nenávisti vưči lidem z Číny a Asie obecně např́klad v nedávných případech v USA, Británii či Brazílii, jak na to upozorňuje respektovaný časopis Nature (Stop the coronavirus stigma now 2020). Pandemie ale může zasáhnout každého a nezná etnika nebo hranice. Světová zdravotnická organizace už v roce 2015 a letos opět důrazně doporučila nespojovat konkrétní nemoc s nějakou lokalitou, zemí nebo regionem, protože to vede ke stigmatizaci a obviňování komunit daných oblastí, ačkoli se každý může stát jejich obětí.

V této souvislosti je třeba ocenit zásilky pomoci s antivirovými pomůckami, které zasílají různé země, včetně Číny, která se ukázala jako hlavní země na světě, která je schopna rychle dodat zásilky roušek, respirátorů a dalších zdravotních materiálů a zařízení do nejvíce postižených zemí, včetně USA či Itálie. Dobře se na tom ukazuje, jak se různé makroregiony světa se svými různými druhy modernit (Weiming 2000; Arnason 2009; Eisenstadt 2016) formovanými odlišnými ekonomicko-politickými systémy a kulturně-civilizační kontinuitami dokážou vyrovnat s pandemií 
a jejími dopady. ${ }^{1}$ Západní modernita není univerzální a má různé alternativy v různých částech světa, včetně alternativy čínské (Wei 2017). Současný ekonomický potenciál Číny se přitom projevuje v její aktivní roli v mezinárodním prostoru i na úrovni širší participace v rámci světových institucí (OSN, Mezinárodní měnový fond, Světová obchodní organizace ad.) i makroregionálních uskupení. Je historicky pozoruhodné (Lysý 2006), že význam „nové asijské hemisféry“ (Mahbubani 2008) s rolí Číny, Japonska a dalších zemí je historickým mezníkem, který se objevuje po více než dvou stech letech výlučné dominance západních velmocí. $V$ době současné pandemie se ukazují priority. Lidé budou v různých modernitách participovat a odvozovat svoji důvěru v politiky i stát předně od toho, do jaké míry jim mohou zajistit bezpečí a ochránit je prozíravými rozhodnutími před životními hrozbami a chaosem.

\section{Východisko z pozastavení}

Téměř na závěr koronavirové vlny v Číně se již od začátku dubna začala čínská společnost a ekonomika krok po kroku otevírat. Samozřejmě nevíme, zda další virová vlna bude jen slabou ozvěnou první vlny jakožto důsledek otevírání, nebo bude opět výrazná. Nicméně podstatné je, že pro revitalizaci ekonomiky je třeba nejen standardní znovuobnovení hospodářství v Číně a v zahraničním obchodu, který se bude revitalizovat jak v závislosti na čínských možnostech, tak rovněž na podmínkách v jiných zemích světa, kde koronavirus působí silněji a zatím blokuje možnosti ekonomické revitalizace.

Čína už má s překonáváním krizí v poslední době zkušenosti. Zvládla asijskou finanční krizi roku 1997, důsledky SARS v letech 2002 - 2004, tzv. globální finanční a ekonomickou krizi roku 2008, která však byla krizí hlavně USA a dalších západní zemí, pandemii H1V1 (prasečí chřipku) v roce 2009 a další výzvy. Důležitá je především zkušenost z krize 2008. Čína ve své ekonomice výrazně zvýšila podíl domácí spotřeby, čímž se stává samostatnější. Nicméně se zároveň snažila řešit problém, že poptávka po čínském zboží v západních zemích se od globální ekonomické krize 2008 začala omezovat. Jelikož v čínské ekonomice hraje export důležitou roli, čínská vláda chtěla pomoci domácím producentům a celkovému stavu ekonomiky. Podpořila budování veřejné infrastruktury a řady dalších projektů v Číně s cílem vyvážit důsledky ekonomické krize a po letech nejistoty na západních trzích se začala aktivně angažovat v mezinárodní a transnacionální oblasti.

V tomto výkladu navazujeme především na analýzy J. Arnasona, G. Delantyho,

G. Therborna a T. Weiminga. 
V letošní situaci koronavirové pandemie náhlé zastavení nebo utlumení masivních toků lidí, zboží a na druhou stranu zrychlení digitalizace, přenosů informací a komunikačních dovedností, elektronického obchodování (e-commerce), práce na dálku apod. vyvolalo v Číně i v dalších zemích světa řadu otázek po důsledcích těchto změn. $V$ různých zemích mohou o práci přijít patrně desítky až stovky milionů lidí a některé podniky a firmy zbankrotují. Pravděpodobné budou dočasné deglobalizační trendy a snahy nahradit globální dělbu práce a výroby lokální a makroregionální soběstačností. Ne vždy to ale bude ekonomicky možné. Pravděpodobné nastanou dočasné deglobalizační trendy, přičemž v některých odvětvích může dojít ke zdravé relokaci a lokalizaci ekonomických aktivit a posílení místních komunit. Nicméně v jiných odvětvích, jako je např́íklad digitalizace, bude planeta propojena ještě více, dokonce i za rámcem planety pomocí satelitů a dalších zařízení. Svět bude stále velice globální v porovnání se stavem například před čtyřiceti, ale i dvaceti lety. Bez celosvětové spolupráce nebude možné účinně čelit planetárním problémům a rizikům včetně epidemií a pandemií.

\section{Historická hedvábná stezka a její modernizace}

Zaměřme se nyní $\mathrm{v}$ druhé polovině tohoto textu na specifikaci možného východiska $\mathrm{z}$ koronavirové krize $\mathrm{v}$ globálním prostředí prostřednictvím výkladu čínských mezinárodních a transnacionálních aktivit, které Čína dosud rozvíjela v posledním období a které již nyní po odeznívání koronavirové vlny v Číně začíná revitalizovat (s nadějí, že druhá či další vlna nebude zásadní překážkou těchto aktivit) (Ho 2020). Vedle různých výrobních a obchodních globálních aktivit by zásadní roli patrně mohla hrát Iniciativa pásma a cesty (anglicky the Belt and Road Initiative, zkratkou BRI). Je proto třeba se ptát, z jakého významného zdroje BRI vychází, jakou roli dosud BRI hrála a jaký je její potenciál do budoucna. Vyhlášení v roce 2013 bylo snahou přijít s novou verzí historické hedvábné stezky, která by byla adekvátní pro 21. století jak obsahem, tak i mediálním obrazem. Pozitivní a částečně rovněž nostalgické vzpomínky na starobylou hedvábnou stezku s karavanami velbloudů, které vezou exotické zboží ceněné v Evropě, Asii i východní Africe, přitahují k nové iniciativě pozornost.

Právě tato globální Iniciativa pásma a cesty může být výrazným podnětem pro revitalizaci ekonomiky v řadě zemí a pro pomoc lidem po pozastavení aktivit kvůli koronavirové pandemii. Nejen čínská administrativa, ale také západní vědci uvažují tímto směrem. Digby James Wren, australský geopolitický expert na Iniciativu pásma a cesty, uvedl: „BRI může působit tak, jak to udělal Marshallův plán, dostal lidi zpět do práce, dal jim 
jídlo na stůl, zajistil, aby lidé dostali zaplaceno, aby měli práci a aby byla vybudována infrastruktura." (Bhaya 2020). BRI by mohla po pandemii pomoci různým zemím světa, ale i Číně samé, analogickým způsobem, jakým Marshallův plán pomohl evropským ekonomikám po druhé světové válce. Finanční objem Iniciativy pásma a cesty je několikrát větší, než byl Marshallův plán (samozřejmě při přepočtu tehdejších financí na finance dnešní).

Peter Thomson, předsedající Valnému shromáždění OSN na plenárním zasedání Fóra pásma a cesty pro mezinárodní spolupráci (Belt and Road Forum for International Cooperation), již dř́ive zdůraznil, že BRI má značný význam nejen pro Čínu, ale i pro světové společenství: „Iniciativa pásu a stezky představuje mocnou hnací sílu pro dosažení cílů udržitelného rozvoje. Inkluzivní, integrační a transformační vize BRI je v naprosté synergii s Agendou 2030 a její optimistický duch inspiruje nás všechny." (Thompson 2017) Čína podepsala přes sto dohod o spolupráci se 126 zeměmi a 29 mezinárodními organizacemi (NewsInAsia 2019). Již nyní se v boji proti pandemii rozvíjí to, co se začíná neformálně nazývat zdravotní hedvábná stezka, která zajišt’uje př́ísun zdravotních pomůcek pro ochranu před koronavirem (dodávky masek, respirátorů, ventilátorů apod.).

Iniciativa pásma a cesty má svoji relevantní historickou předchůdkyni ve zmíněné proslulá historické hedvábné stezce, jež byla organickou součástí dlouhodobého vnitřního rozvoje Číny, která vynalezla a produkovala zboží atraktivní také pro ostatní části Asie, Evropy i Afriky. ${ }^{2}$ Hedvábnou stezku tvořila transnacionální sít' pozemních i námořních cest, propojující civilizace, národy, etnika a náboženství od Číny až po římskou říši. Zahrnovala tak Eurasii od východu Asie přes Indii, Střední Asii, Persii, arabský svět až po Balkán s odbočkami do východní a severní Afriky. Stezka získala slávu nejen díky čínskému hedvábí, ale také prostřednictvím řady dalších produktů (papíru, tisku, kompasu, střelnému prachu či jeřábu) a nových myšlenek. Stezka sloužila výměnám zboží a také civilizačních, kulturních, sociálních, filosofických, vědeckých, vojenských či politických výdobytků a vynálezů i širrení rozmanitých zájmů a cílů.

Od svého vzniku ve 2 . století př. n. l. hedvábná stezka pochopitelně zažívala i temnější chvíle, kdy docházelo k útlumu vzájemných výměn. Ve svých dlouhých dějinách byla svědkem např́íklad šíření epidemií přenášením moru a jiných infekčních nemocí, a to jak z Východu na Západ, tak obráceně. Pokaždé však v dějinách výhody převážily nad deficity a pohyb lidí a zboží se obnovil a rozvinul ještě více než před epidemií.

Zde čerpáme z článku zaměřeného na historické zdroje čínského modelu a revitalizované hedvábné cesty v moderní verzi (Hrubec 2020, 141-143). 
Hedvábná stezka byla po dobu přibližně šestnácti století významným příspěvkem ke světovým dějinám díky tomu, že podněcovala spolupráci mezi Východem a Západem. Bez hedvábné stezky by dnes zbytek Asie, Evropa a Afrika nejspíš vypadaly jinak, protože tehdejší inovace se šírily především z Východu na Západ (Frankopan 2017).

\section{Iniciativa pásma a cesty a scénáře dalšího vývoje}

Iniciativa pásu a stezky byla navržena roku 2013 s cílem navázat moderním způsobem na dědictví staré hedvábné stezky. Od té doby se rozvinula v ambiciózní projekt zaměřený na rozvoj konektivity, komunikace a spolupráce mezi zeměmi a regiony v Asii, Evropě, Africe a rovněž Latinské Americe, tedy projekt, který by mohl být vhodným prostředkem také pro revitalizaci ekonomických a dalších aktivit po koronavirové epidemii. Je už na co navazovat. Od spuštění iniciativy do června 2018 obchod mezi participujícími zeměmi překonal 5 bilionů dolarů. Během prvních pěti let Čína v těchto zemích investovala přes 70 miliard dolarů. $V$ př́padě inženýrských projektů hodnota kontraktů převýšila 500 miliard dolarů. BRI již vynesla 2,01 miliardy na daních a vytvořila 244 tisíc pracovních míst (Lu 2018). Známé ekonomické koridory propojují Eurasii a zahrnují například projekt železnice Budapešt'-Bělehrad či celou řadu projektů v rámci CPEC, tedy koridoru Čína-Pákistán, jenž umožňuje přístup Číně do Perského zálivu k arabským zemím a také k Iránu, který dnes patří k zemím nejvíce postiženým koronavirem. Za zmínku rovněž stojí čínské investice do přístavů po celém světě, včetně evropských, například v Řecku či Itálii, jež patří k evropským zemím s největším výskytem nakažených koronavirem.

Iniciativa pásma a cesty není izolovaným projektem, který jen dobře navazuje na historii a byl by nyní kvůli pandemii využit pouze krátkodobě a účelově. Je relevantní součástí širšího rámce konceptu čínského snu (中 国梦, Zhongguo meng), který počítá s vybudováním přiměreně prosperující společnosti v roce 2021 a rozvinuté společnosti v roce 2049 , kdy země oslaví sté výročí založení Čínské lidové republiky. Součástí je rovněž podpora domácí spotřeby, která má za cíl snížit závislost na čínském exportu zvláště na Západ, respektive do USA. Globální rozměr transformace pak spočívá v reformulaci dosavadní zahraniční politiky a tvorbě globálních institucí (Wu 2018). Kromě Iniciativy pásu a stezky jde o např́íklad o Asijskou infrastrukturní investiční banku (AIIB), která je rozvojovou bankou určenou pro budování infrastruktury v Asii i za jejími hranicemi, čímž doplňuje a umenšuje význam a činnost Světové banky a Mezinárodního měnového fondu. Proto BRI zdůrazňuje transnacionální a globální produkci, obchod a další formy spolupráce, jakož i domácí rozvoj v Číně spojený s globálními 
interakcemi s jednotlivými světovými makroregiony světa a zároveň zaměřený na propojení čínských provincií, z nichž obzvláště ty západní zůstávají stále poměrně nerozvinuté.

Nyní ale bude záležet na tom, jak bude potenciál uvnitř Číny i její aktivity provazující interní a externí aktivity, především Iniciativy pásma a cesty, využity jako východisko při odeznívání koronavirové pandemie. Šanghajské ústavy mezinárodních studií přicházejí se třemi základními scénáři potenciálního ekonomického vývoje (Chen 2020, s. 8-10). První scénář, teorie „kritického dopadu“ (the "critical impal” theory), počítá se silnými negativními konsekvencemi pandemie. Předpokládá, že pozastavení ekonomiky v době pandemie nebude následováno hladkým rozjezdem do téměř původního stavu ekonomiky, ale naopak problematizováním již zpomalené čínské ekonomiky a následným dopadem na světovou ekonomiku. Druhý scénář, teorie „zvládnutelného dopadu“ (the "manageable impal” theory), vychází z řešení ekonomických konsekvencí po virové epidemii SARS kolem let roku 2003. Vychází tedy v možnosti kontrolovatelného menšího negativního dopadu na čínské hospodářství a překonání propadu v prvním čtvrtletí 2020, což by mělo mít pouze mírné negativní důsledky v mezinárodní a transnacionální sféře. Za třetí, teorie „nejistého dopadu" (the "uncertain impal" theory) rozpracovává další faktory možného vývoje, včetně nejistého času trvání pandemie, které nemají dostatečný precedens $\mathrm{v}$ minulosti a jež tedy nelze dobře predikovat $\mathrm{v}$ budoucím vývoji. Například skutečnost, že velikost čínské ekonomiky je v současné době devětkrát větší než v roce 2003 , kdy propukl SARS.

Důležitým bude přístup, který v Číně v současné době zaujmou v rámci př́prav na plán na leta 2021-2025, včetně ekonomických stimulů na revitalizaci ekonomiky po období pandemie. Pokračování v infrastrukturních projektech $v$ Číně i v rámci Iniciativy pásma a cesty, budování sítě $5 \mathrm{G}$ a umělé inteligence a další směřování k ekonomice s vysokou přidanou hodnotou a rozvinuté společnosti budou patřit mezi určující trajektorie dalšího vývoje.

\section{Spolupráce 17+1: kooperace Číny se střední a východní Evropou}

Podívejme se nyní, jak by se další vývoj v Číně po pandemii mohl dotknout střední Evropy v rámci uplatnění Iniciativy pásu a cesty a Spolupráce 17+1. ${ }^{3}$ Zatímco platforma 16+1, respektive od jara 2019 díky zapojení Řecka s jeho strategickým přístavem Pireus u Athén 17+1, může být pojímána v užším smyslu a samostatně, v širším rámci tvoří součást Iniciativy

Na tomto místě využíváme komparativní rozbor BRI ve vztahu ke spolupráci v rámci 16+1 (Hrubec 2018b). 
pásu a cesty. Formát 16+1 byl vytvořen s cílem rozvíjet strategický dialog a spolupráci mezi ČLR a šestnácti středoevropskými a východoevropskými zeměmi (region CEE) a poté začal být rozvíjen rovněž v kontextu BRI. $\mathrm{V}$ obou př́padech je obsah tvořen rozmanitými projekty $\mathrm{v}$ oblasti investic, energetiky, dopravy, obchodu, výzkumu, vzdělání, kultury či životního prostředí (Huang - Liu 2016). V rámci BRI dosud čínské vedení kladlo důraz na infrastrukturu, high-tech i zelené technologie. Formát 16+1 sice v roce 2012 iniciovala Čína, aktivně se na něm nicméně podílejí i ostatní partneři z regionu CEE.

BRI i spolupráce na platformě $17+1$ představují ambiciózní projekty a jako takové pochopitelně přinášejí i určitá rizika, která je třeba řešit. Nové výzvy jsou spjaty s rozvojem a šířením umělé inteligence, sítí $5 \mathrm{G}$, internetu věcí, kybernetickou bezpečností, novými sociálními médii či e-commerce. Založení nové verze Světové obchodní organizace odpovídající novým trendům a uvedené agendě v podobě Elektronické světové obchodní platformy (eWTP) může být jedním z dalších zásadních kroků. Nové tendence a nové problémy by nicméně měly být chápány jako výzvy a př́ležitosti, které jsou nutnou podmínkou jakéhokoli rozvoje, inovace a pokroku.

Projekt 17+1 i Iniciativa pásu a stezky jako taková sdílejí úsilí o prohlubování strategického dialogu, konektivity a spolupráce mezi jednotlivými částmi a větvemi. Jsou však mezi nimi i rozdíly, které je třeba průběžně analyzovat a navrhovat řešení různých specifik, které z toho plynou. Platforma 17+1 se zaměřuje primárně na oblast střední Evropy, Pobaltí a Balkánu, zatímco BRI na mnohem rozsáhlejší oblast Asie, Evropy, Afriky a Latinské Ameriky. Prvním, zjevným rozdílem je tedy územní rozměr. Sedmnáctka států je přece jen něco jiného než čtveřice kontinentů. Za druhé, panuje rozdíl ve vnitřní koherenci. Na jedné straně BRI zahrnuje země s nanejvýš odlišnými dějinami, ekonomikou, politikou či kulturou, třebaže některé sdílejí společné eurasijské základy. Na straně druhé je výhodou šestnáctky zemí z formátu 17+1, že rozvíjejí specifickou a mnohem méně diferencovanou formu spolupráce. Navzdory objektivně existujícím rozdílům má těchto šestnáct států společnou socialistickou minulost a podobné zkušenosti s ekonomickou a politickou transformací a přechodem k tržnímu hospodářství po roce 1989 (kromě Řecka, které však má po své nedávné krizi podobné výkonnostní ekonomické charakteristiky jako šestnáct ostatních zemí). V tomto ohledu se částečně podobají čínské zkušenosti, nebot' Čína od roku 1978 rovněž prochází výrazným transformačním procesem. Za třetí, rozdíl v teritoriálním záběru a vnitřní soudržnosti vede k různým podobám spolupráce. Ta může být sice na platformě $17+1$ 
mnohem intenzivnější a rozvinutější, ale plně rozvinout se bude moci až v pevném spojení a v rámci BRI.

Všechny tři zmíněné rozdíly mohou Iniciativu pásu a stezky obohatit, pokud se je podaří uchopit jako možnosti rozvoje. Specifickou úlohu hrají středoevropské země, především V4, tedy Česká republika, Slovensko, Mad’arsko a Polsko. V projektu $16+1$ byly v posledních letech velmi aktivní. Doposud státy V4 a Rumunsko tvořily přibližně $80 \%$ obchodu mezi Čínou a státy CEE. Spolupráce se ale pochopitelně neomezuje pouze na obchod. Naopak zahrnuje také další oblasti - ekonomickou, finanční, právní, výzkumnou, vzdělávací, kulturní či mezilidskou. Celkově by 17+1 mohla pomoci zvýšení životní úrovně občanů $17+1$, a tak přispět k tomu, aby se tyto země staly plnohodnotnějšími partnery bohatších západoevropských zemí Evropské unie. To by mělo být v zájmu celé EU.

V Česku, na Slovensku i obecněji ve střední Evropě budeme muset v dalším období po pandemii v souvislosti s realizováním vazeb s čínskými partnery čelit mnoha výzvám a překážkám, které bude třeba překonávat (Hrubec 2018). Členové $17+1$ budou přitom pokračovat v intenzivní kooperaci se západními zeměmi Evropské unie a také ve spolupráci s ostatními partnery v rámci multilaterálního světa. Bude to znamenat pokus o nové nastavení vztahů s USA, rozvoj vztahů se zeměmi BRICS a dalšími většími i menšími státy $\mathrm{v}$ rámci Iniciativy pásu a cesty a $\mathrm{v}$ dalších iniciativách. ${ }^{4}$

\section{Závěr}

Globální pandemie otevřela celou řadu důležitých otázek. Pomohla obnažit problémy, které se skrývaly pod povrchem. Přenos viru z prŕrodního prostředí do lidské společnosti není jen záležitostí konkrétního případu koronaviru. Má obecnější souvislosti, které poukazují na další formy přenosů, které se projevily v jiných případech. Týkají se ekologických problémů souvisejících $\mathrm{s}$ přetěžovaným životním prostředím a měly by vést k proměně výroby, distribuce a spotřeby směrem $\mathrm{k}$ „udržitelným“ a méně devastujícím způsobům produkce.

V krizi akcelerující potřeba využití nových technologií vynucená znemožněním běžného fyzického sociálního kontaktu může být vnímána jak z perspektivy rozšíření možností člověka a společnosti, tak i z perspektivy rizik digitální kontroly se sofistikovaným zpracováním biologických dat. Rozvoj robotizace a automatizace může vést k pozitivnímu nahrazení

$4 \quad \mathrm{~K}$ dalším rozborům mohou sloužit knihy o interkulturním dialogu a různorodých modernitách (Hrubec 2008; Svoboda - Štěch 2012; Kreuzzieger - Lánský 2016; Agha 2018). 
lidské práce strojovou, jak o tom sní již celé generace lidí, ale zároveň může vést k nezaměstnanosti, pokud nebudou pozitivní př́nosy z robotizace rozděleny mezi celou lidskou populaci.

Jsou zde i globální ekonomické a politické otázky spojené se změnami po pandemii. Ekonomická spolupráce USA, Evropy a Číny od roku 1978 vytvořila provázaný komplexní globální systém, který Čína dokázala v domácím prostředí využít pro svůj rozvoj, konkrétně pro vyzvednutí $800 \mathrm{mi}$ lionů lidí z chudoby a zvýšení životní úrovně, z toho více než 300 miliónů lidí na úroveň Evropské unie. Avšak od nástupu nového amerického prezidenta v roce 2017 se prohlubuje divergence a rivalita mezi USA a Čínou.

Dnes už ale víme, že střety velmocí, modernity či civilizací na globálně sdílené a propojené planetě si nikdo nemůže dovolit, aniž by tím neohrozil i sám sebe. Je zapotřebí respektovat pluralitu uspořádání v různých makroregionech světa i v menších oblastech a společně kooperovat. Iniciativy Pásma a cesty a 17+1 k tomu dávají př́iležitost. Spolupráce na globální rovině je potřebná nikoli z čistého idealismu, ale z řady praktických důvodů, které lidem umožnily zvládnout překážky nepřekonatelné pro malá společenství. Pandemie koronaviru je právě takovým závažným globálním problémem, který se týká života, bezpečnosti a zdraví všech lidí.

\section{Literatura}

AGHA, P. (2018): Lidská práva v mezikulturních perspektivách. Praha: Academia. ARNASON, J. P. (2009): Civilizační analýza. Evropa a Asie na rozcestí. Praha: Filosofia.

BARRO, R. J. - URSUA, J. F. - WENG, J. (2020): The Coronavirus and the Great Influenza Epidemic Lessons from the "Spanish Flu" for the Coronavirus's Potential Effects on Mortality and Economic Activity. Munich: Munich Society for the Promotion of Economic Research - CESifo GmbH.

BHAYA, A. G. (2020): BRI to lead post-COVID-19 "Marshall Plan" for global recovery. In: CGTN, 11. 4. 2020. Web. 26. 4. 2020. <https://news.cgtn.com/ news/2020-04-11/BRI-to-lead-post-COVID-19-Marshall-Plan-for-globalrecovery-Pyun62Fl7y/index.html>.

CHEN, D. et al. (2020): Coronavirus Battle in China: Process and Prospect. Shanghai: Shanghai Institutes for International Studies, s. 8 - 10.

DELANTY, G. (ed.) (2006): Europe and Asia Beyond East and West. London - New York: Routledge.

EISENSTADT, S. N. (2016): Různorodé modernity. In: Kreuzzieger, M. - Lánský, O. (eds.): Modernita/modernity v eurasijských kulturních a civilizačních kontextech. Filosofia, Praha: s. 133 - 165.

FRANKOPAN, P. (2017): The Silk Roads: A New History of the World. New York: Vintage. 
HO, D. (2020): COVID-19 won't have long-term impact on BRI. In: China Daily 26.3.2020.Web.30.4.2020.<https://global.chinadaily.com.cn/a/202003/26/ WS5e7c0e74a310128217282227.html .

HUANG, P., LIU, Z. (eds.) (2016): China-CEEC Cooperation and the "Belt and Road Initiative". Beijing: China Social Sciences Press.

HRUBEC, M. (ed.) (2008): Interkulturní dialog o lidských právech. Praha: Filosofia.

HRUBEC, M. (2018): Approaches of the EU towards the 16+1 Cooperation: Three Cases in the Framework of the Belt and Road Initiative. In: Huang, P. - Liu, Z. (eds.) 16+1 Cooperation and the Belt and Road Initiative: Europe's Responses. Beijing: China Social Sciences Press, s. $97-108$.

HRUBEC, M. (2018b), Innovation in Understanding and Cooperating the MacroRegions. In: HUANG, P., LIU, Z. eds. How the $16+1$ Cooperation Promotes the Belt and Road Initiative. Beijing: China Social Sciences Press, pp. $34-53$.

HRUBEC, M. (2020): Historical Resources of China's Model: Relevance to the Present. In: Human Affairs, 30 (2), $134-145$.

KREUZZIEGER, M. - LÁNSKÝ, O. (eds.) (2016): Modernita/modernity v eurasijských kulturních a civilizačních kontextech. Praha: Filosofia.

LU, Y. (2018): China's merchandise trade with Belt and Road countries tops $\$ 5$ trillion in 5 years. In: People's Daily 31. 8. 2018. Web. 30. 4. 2020. <http://en. people.cn/n3/2018/0831/c90000-9496013.html>.

LYSÝ, J. (2006). Dejiny politického myslenia (Blízky Východ, Antika, Čína, India, Islam). Bratislava: Univerzita Komenského.

MAHBUBANI, K. (2008): The New Asian Hemisphere: The Irresistible Shift of Global Power to the East. New York: Public Affairs.

MAZZETTI, M. - E. BARNES, J. E. - WONG, E. - GOLDMAN, A. (2020): Trump officials are said to press spies to link virus and Wuhan labs. The New York Times 30. 4. 2020. Web. 30. 4. 2020. <https://www.nytimes.com/2020/04/30/us/ politics/trump-administration-intelligence-coronavirus-china.html>.

MULRANEY, F. - OWEN, G. (2020): Revealed: U.S. government gave \$3.7million grant to Wuhan lab. In: Mail Online. 12. 4. 2020. Web. 30. 4. 2020. <https:// www.dailymail.co.uk/news/article-8211291/U-S-government-gave3-7million-grant-Wuhan-lab-experimented-coronavirus-source-bats.html>.

NOLAN, P. (2019): China and The West. Crossroads of Civilisations. London: Routledge.

ORBEY, E. (2020): Trump's “Chinese Virus” and What's at Stake in the Coronavirus's Name. The New Yorker 25. 3. 2020. <https://www.newyorker.com/culture/ cultural-comment/whats-at-stake-in-a-viruss-name>.

PICKRELL, R. (2020): Chinese official says US army may have "brought the epidemic to Wuhan". In: Millitary.com 12. 3. 2020. Web. 30. 4. 2020. <https:// www.military.com/daily-news/2020/03/12/chinese-official-says-us-armymay-have-brought-epidemic-wuhan.html>.

Stop the coronavirus stigma now (2020): In: Nature 7. 4. 2020. Web. 13. 4. 2020. <https://www.nature.com/articles/d41586-020-01009-0>.

SVOBODA, J. - ŠTĚCH, O. (2012): Interkulturní vojna a mír. Praha: Filosofia. 
THOMPSON, P. (2017): Speech at the Plenary Session of the Belt and Road Forum for International Cooperation. The Belt and Road Forum for International Cooperation. Beijing, 14. 5. 2017.

WEIMING, T. (2000): Multiple Modernities: A Preliminary Inquiry into the Implications of East Asian Modernity. In: Harrison, L. E. - Huntington, S. P. (eds.): Culture Matters: How Values Shape Human Progress. New York: Basic Books.

WINTOUR, P. (2020): US intelligence agencies under pressure to link coronavirus to Chinese labs. In: The Guardian 30. 4. 2020. <https://www.theguardian.com/ world/2020/apr/30/cia-pushes-back-at-trump-efforts-to-link-coronavirusto-chinese-laboratories $>$.

Worldometers (2020): Web. 27. 4. 2020. <www.worldometers.info/coronavirus/>. WEI, X. (2017): Ekonomická a politická transformace Číny. Praha: Filosofia.

WORLD HEALTH ORGANIZATION (2020): Origin of SARS-CoV-2. 26. 3. 2020. Web. 30. 4. 2020. <https://www.who.int/health-topics/coronavirus/whorecommendations-to-reduce-risk-of-transmission-of-emerging-pathogensfrom-animals-to-humans-in-live-animal-markets>.

WU, Z. (2018): Funcional Logic of the Belt and Road Initiative: Based on a New Interpretation of Geo-economics. In: SASS Studies, 12, 28 - 68.

126 countries, 29 international organizations are now part of China's BRI (2019): In: NewsInAsia, 29. 4. 2019. Web. 30. 4. 2020. <https://newsin.asia/126countries-29-international-organizations-are-now-part-of-chinas-bri/>.

RNDr. PhDr. Milan Kreuzzieger, PhD.

Centrum globálních studií

Filosofický ústav Akademie věd ČR

Jilská 1, 11000 Praha 1

Česká republika

kreuzzieger@flu.cas.cz

doc. PhDr. Marek Hrubec, PhD.

Centrum globálních studií

Filosofický ústav Akademie věd ČR

Jilská 1, 11000 Praha 1

Česká republika

hrubec@flu.cas.cz 